\title{
Civil society, democracy promotion and Islamism on the Southern shores of the Mediterranean
}

Dr. Francesco Cavatorta

School of Law and Government

Dublin City University

Dublin 9, Ireland

E-mail: Francesco.cavatorta@dcu.ie 
Janine Clark, Islam, Charity and Activism; middle-class networks and social welfare in Egypt, Jordan and Yemen, Bloomington, Indiana University Press, 2004

Nicola Pratt, Democracy and Authoritarianism in the Arab World, Boulder, Lynne Rienner, 2007.

Amaney Jamal, Barriers to Democracy; the other side of social capital in Palestine and the Arab World, Princeton, Princeton University Press, 2007.

Nicolas Beau and Catherine Graciet, Quand le Maroc Sera Islamiste, Paris, Ed. La Découverte, 2006.

\section{Introduction: civil society in the Arab world}

Policy-makers and scholars consider the persistence of authoritarian rule in the Arab world as the most significant obstacle to international peace and stability, making democratisation a priority. With the failure of democracy by imposition, much greater attention is paid to non-military means of democracy promotion and the strengthening of civil society has come back to the top of the agenda. Thus, both the US and the European Union intensified their financial and political commitments to increase civil society activism in order to generate democratising pressures from below. Due to the relevant political role that that the international community assigns to civil society, it is no surprise that a number of recent publications deal with this topic.

The concept and practical application of the term 'civil society', after enjoying a spell of academic popularity, had recently come under criticism. From a theoretical point of view, it seems that the concept is too vague and normative to be of much use when explaining complex processes of democratisation (Encarnacion, 2006; 
Carothers, 1999/2000). From an empirical point of view, it emerges that the role assigned to civil society in undermining the regimes of Eastern Europe has been greatly exaggerated (Tempest, 1997). However, when it comes to the Arab world, the debate about the role, strength and normative value of civil society is still alive. First of all, the realm of civil society is the one where opposition politics currently takes place due to the weakness of political parties. Secondly, it is within civil society that Islamism is particularly active through a number of charitable activities and its political credibility is largely derived from its welfare work. Thirdly, international actors implement strategies of democracy promotion through the funding of civil society activism to achieve democratising goals. Finally, the ruling elites have invested the terrain of civil society in order to control it and incorporate it.

Broadly speaking there are four views regarding the state and relative importance of civil society in the Arab World. The first view treats the concept of civil society as being exclusively a liberal normative one and argues that in the region such civil society is very weak and therefore unable to pressure the regime into making democratic reforms. There are only very few liberal-democratic civil society organisations that promote and defend democratic values (Yom, 2005) and the state is able to dismantle or co-opt them. The second view conceptualises civil society in neutral terms and argues that civil society activism is quite strong when Islamist groups are included. The argument is that civil society organisations do not have per se any normative liberal-democratic traits and do not necessarily promote liberal values. Civil society can be therefore strong and 'uncivil' at the same time and this is precisely what Berman (2003) argues with respect to Arab civil society given the overwhelming presence of Islamists, who have an anti-democratic ethos. The third view suggests that civil society has indeed been strengthening over the last decade, 
with a significant surge in the numbers of organisations being created. However, this is not necessarily a sign that the ruling elites are losing control of their own society. Quite the contrary is true, as many civil society organisations are largely creations of the state itself, while others are either beholden to the state or fully co-opted. This generates an artificial civil society where autonomy of action is limited (Wiktorowicz, 2000). The fourth view suggests that civil society should indeed be treated as a neutral explanatory category, but it also suggests that Islamism should not be a priori treated as possessing an authoritarian nature (Brumberg, 2002; Cavatorta, 2006). It follows that the strength of civil society should be examined through the dynamics that occur between its different sectors.

The four volumes under review broadly fit in these schools of thought and address issues that are prominent in the debates between all of them. At the same time, they challenge some received wisdoms of the scholarship of civil society and on the scholarship of its conceptualisation in the Arab world.

\section{Civil society dynamics under authoritarian rule}

Pratt examines the evolution of civil society activism in a number of Arab republics since independence and her analysis is concerned with explaining how authoritarian rule has been able to survive, using civil society as an explanatory variable. She claims that 'the Arab world has failed to experience a transition to democracy not because civil-society actors do not support democracy, but because there does not exist a consensus that challenges the post independence hegemony underpinning authoritarianism' (2007:189). Due to colonialism, civil society activism was intimately linked to the struggle for independence and to nationalism. Thus, the specific social or class interests of certain groups such as women, workers or 
minorities were subsumed within the nationalist ideology. To a large extent this was a voluntary submission because they all shared the desire to be independent and 'to construct a national identity and culture that was modern but not Western' (2007:33). Civil society actors shared the objectives of modernisation, namely economic progress and anti-imperialism, and were therefore willing to sacrifice their particular struggles to achieve such objectives. Ultimately, this favoured the solidification of authoritarian rule because national identity and national unity became the primary referents for legitimate political action. In the name of national unity, dissent was labelled as anti-patriotic and therefore repressed. Once the project of post independence modernisation failed to deliver economic success, international equality and domestic social progress, civil society began to turn against the ruling elites. The problem is that such dissent did not coalesce around liberal and democratic notions. Thus, while, liberal and secular activism is now present in Arab civil society, the Islamists overshadow it. The pre-eminence of Islamism is due to its ability of reenergising the modernisation impetus through religious precepts and symbolism. It follows that while the new civil society actors sharply criticise the authoritarianism of the political system, the dominant Islamist alternative largely proposes the same corporatist arrangements of the past, although underpinned by a different ideological referent. In the past, civil society organisations had subordinated 'the welfare and rights of ordinary citizens to those of the national collective' (2007:59). This is today unacceptable not because of the intrinsic deficiencies of such arrangements, but because they are not sufficiently strong. Thus they need to be strengthened and reinfused with new vigour. This generates the current opposition to the ruling elites within civil society, but Pratt claims that this is not truly a challenge because a democratic counter-discourse has not been fully developed given the marginal role of 
secular and liberal organisations. In fact, civil society activism remains very much linked to the necessity of rediscovering a unitary élan of modernisation that seems to have been lost throughout the years. This interpretation of the development of civil society activism leads to a number of considerations on the current situation. First of all, it explains the popularity of Islamic activism. While on the surface Islamism is in opposition to the current regimes, it offers simply a re-invention of previous corporatist arrangements, this time imbued with the traditional values of religiosity which will ensure against corruption and secular and individualistic tendencies. Islamism is popular because it offers ordinary citizens an ideological framework very similar to the one of post-independence nationalism within which the original goals of modernisation can be achieved. The example of the Algerian FIS presenting itself as the true heir of the anti-colonial struggle is still a valid illustration of how this process works. Thus, Islamism proposes a 'catch-all' discourse that replaces secular nationalism with a religious one, which is appealing to broad sections of the population irrespective of their social and individual status. The project of political Islam is a totalising one because it simply re-frames the conceptual categories which the previous national consensus was built on in religious terms. In addition, Islamist groups and associations are practically able to demonstrate that their ideological references are 'concrete' in so far as they provide for the welfare of citizens as much as the early nationalist elites were able to do immediately after independence. Through their networks of social activism, Islamists are able to offer a glimpse of the promise of the continuation of non-Western modernisation that ruling elites betrayed. Secondly, Pratt's tracing of civil society development explains the limited appeal of secular and liberal groups. Their discourse is only marginally effective precisely because it does not offer 'total' solutions and because their idea of modernisation is 
very much in line with a Western one. This cannot be very appealing at a time when Western policies do not enjoy much prestige and Western societies appear 'a-moral'. Pratt's contribution is interesting because it presents us with a 'historical' explanation for the inability of civil society to truly challenge authoritarianism in so far as the dominant counter-discourse, Islamism, is still imbued with notions of exclusivist identities. Islamists still pretend that the welfare and rights of citizens can be advanced only through a unitary project that does not accept deviations in the name of social and individual differences and needs. To a certain extent, Pratt's work can be linked to the first school of thought mentioned above because it highlights the inability of a normative liberal notion of civil society to assert itself in the Arab world and to press for change. She recognises for instance the weakness and divisions that plague secular and liberal human rights associations and women's groups. While heir work is both important and necessary to try to spread universal values of equality and individual rights, they are largely marginal actors. While not going as far as labelling Islamist groups as inherently anti-democratic, Pratt points to very real difficulties that opposition actors of a liberal and secular inspiration have in dealing with Islamists. The opposite is also true in that Islamist organisations have tremendous problems in finding common ground with secular civil society. From this, it follows that civil society, despite its strength, is currently unable to challenge authoritarian regimes in the name of shared democratic values. Finally, from a policy-making point of view, it means that the efforts of the international community to promote democracy through civil society activism are quite ineffective because the groups that enjoy the support of international actors have little domestic credibility and more often than not tend to cooperate with the regime, thus reinforcing their authoritarian grip on society. This view of civil society activism can contribute to explain the absence of meaningful 
alternatives to the current regimes in power, although it is admittedly based on an 'ideal type' categorisation of associations into Islamist and secular/liberal.

The problem with this interpretation is the sharp distinction made between Islamist groups and non-Islamist ones. The reality is probably much more complex and Jamal's book contributes to better understand it. Her research also deals with divisions among movements active within associational life, but she prefers the labels pro and anti regime groups. Jamal specifically analyses how civil society dynamics in authoritarian contexts lead to reinforce authoritarian rule and how an increase in trust and social capital has reverse effects on attitudes towards democracy. The literature on civil society postulates that democratic change stems from the close correlation that exists between a vibrant associational life, the generation of social capital and the growth of democratic values and attitudes. However, Jamal challenges this assumption and argues that associational life in authoritarian contexts is distinctively different from the one in established democracies. The dynamics that are produced in the relationships between authoritarian regimes and civil society organizations are fundamentally different despite the fact that similar trends, such as the increase in interpersonal trust among association members, exist in both authoritarian and democratic contexts. The argument, similar to the one of the third school of thought, is that the authoritarian constraints the regime put in place make it necessary for associations to decide which side they are on. If the association wants to achieve some of its objectives, it will have to play by the rules of the authoritarian regime. Thus, it is only through corrupt networks of patronage that the association will be able to satisfy the basic needs of its members and achieve its goals because only the regime can deliver the 'goods.' These networks however reinforce the central role of the authoritarian regime because they strengthen non-democratic access to decision- 
makers. Paradoxically, social capital increases within these pro-regime associations because their members, by playing within the constraints provided, can be reasonably certain of positive outcomes for the group, which then has no interest in dismantling such networks in favour of fairer and more democratic ways of access to decisionmakers because this would diminish their benefits. The opposite is also true and antiregime organisations, which do not utilise or do not have patronage networks available to them, have lower levels of social capital because of their more democratic values, which do not allow them to obtain the same level of benefits. The pro and anti-regime labels are probably more effective than the Islamist and secular/liberal ones because they better capture the personalistic nature of many these networks, which at times are much more significant than ideological differences. Jamal does not write off the difficult work of many autonomous anti-regime organisations, but civil society in the end does not produce democratisation because authoritarian dynamics provide a very rigid structure of incentives for associational life and do not permit the emergence of democratic attitudes. The policy-making implications of these findings point, once again, to the ineffectiveness of international democracy promotion strategies. As long as political systems in the Arab world remain authoritarian, civil society activism will not develop and will not play the same role as in established democracies. As long as material benefits to associations are distributed through regime-controlled corrupt networks, which reinforce patronage the threat of violence, very little can be achieved. Groups that benefit will not develop democratic attitudes and it is precisely those groups that the regimes count on for ensuring survival. 


\section{$\underline{\text { Islamism and civil society }}$}

There is a considerable degree of consensus on the Islamist virtual dominance of associational life as Islamists are active in a wide number of fields. Irrespective of one's normative views about Islamism, Islamic activism needs to be examined because it represents a crucial aspect of the vibrancy of civil society.

The pre-eminence of Islamist organisations within civil society is at the centre of Clark's volume, which can be loosely linked to the fourth school of thought. It examines Islamic social institutions and how they operate in the provision of social welfare. In a sense Clark explores in detail what Pratt has highlighted and she argues that 'Islamic social institutions represent a moderate response not only to the secular state's inability to provide social welfare services but against the secular state as well' (2004:12) This ideological and teleological goal however has to contend with the structural realities and constraints of the environment surrounding Islamic organisations. Clark convincingly argues that these constraints make Islamist associations not so different to their secular counterparts. In this respect, the findings from the case studies challenge some received wisdoms precisely because organisations are examined as rational actors and not simply as ideological ones, unable to accept the 'reality' of their institutional, social and economic environment. There are three important conclusions that Clark makes. Firstly, while it is confirmed that Islamic social institutions are more active than their secular counterparts and, at times, more active than the state itself in providing welfare services, their activism does not present tangible Islamic ideological references. Thus, 'there is no conscious attempt to create the foundations for an Islamic vision of society' (2004:152). This means that the way in which Islamic charities are run responds more to demands of efficiency than to political or ideological requisites. Organisational matters, efficient 
delivery of service and long-term sustainability the association itself are much more relevant than 'planting the seeds of a new understanding of state and society' (2004:152). The conventional wisdom that such Islamic institutions are a significant recruiting ground for the Islamist political project and that they are purely ideological actors bent on propagating a political message is proven wrong. These organisations are very much aware of the environment they operate in and make the necessary compromises in order to fulfil their primary objectives, which are not necessarily political. In fact what makes such institutions Islamic is simply the belief of many individuals involved that they 'are promoting Islam through their work' (2004:153). This means that Islamic institutions do indeed operate and socialise their members in much of the same way as it happens elsewhere and that they should be treated as rationalistic actors. The second important finding is that Islamic charities are very much a middle class product and are run by and for middle-class professionals. While Clark acknowledges that such charities do have programmes for the poor, their primary function is to employ and serve middle-class professionals and families that the state cannot or will not support. Against conventional wisdom again, the vast masses of poor and disenfranchised are not organically integrated in an Islamist political and social project. Rather, 'the poor...are excluded from the social networks which lie at the heart of the Islamist movement' (2004:154). If correct, this middle class bias is significant in two ways. First of all, it might undermine in the long term the commitment to radical social change of the Islamist movement because it can be accused of abandoning the reason which gives it popularity, namely the commitment to help the less fortunate. Secondly, it means that the 'poor' are largely up for grabs as a constituency and that political groups with a different ethos can be successful in attracting them if they can outperform Islamic charities in providing welfare. The 
third finding is that Islamic charities are much more practical than expected when it comes to their relations with the regimes and use access to it to achieve their goals. Contrary to expectations, many Islamist groups operating as service-providers are dependent on the state because they need the regime's cooperation on a number of issues such as licensing or building permissions. In this respect they privilege efficiency of action over futile confrontations that might hinder their capacity to act and therefore act rationally in order to advance the associations' concrete goals. In many ways this also confirms Jamal's point about associational life being somewhat a pillar of authoritarianism.

Broadly speaking, the work of Beau and Graciet on Morocco fits in with the fourth school of thought on civil society activism because their examination of Islamism and secular associational life does not suffer from a priori assumptions about the democratic nature of the actors engaged in civic and political activism. When it comes to the analysis of Islamism 'in action' they seem to contradict some of the findings in Clark's book. This applies in particular to the idea that Islamism is largely a middle-class phenomenon. In their survey of Morocco's political, economic and social state of affairs, the two authors give considerable space to the operations of Sheikh Yassine's Justice and Charity Group. From their analysis it emerges that many of the charitable associations linked to the group are indeed run by and for the professional Moroccan middle-class, which opposes the monarchy for its authoritarianism, corruption and inability to solve Morocco's problems. However, many of the activities are not profit making and are run on a volunteer basis for the benefit of the very poor sections of the population. While the range of services might not be not of the same high quality as the one offered in the cases Clark addresses, such services are still crucial in attempting to lift men and women out of economic 
distress and illiteracy. The focus is thus on literacy classes, job training and basic medical care. Thus, while it is probably true that even the Justice and Charity Group serves, to a certain extent, the professional needs of the middle class, the popularity of the Islamist movement indicates that their social work still carries considerable weight with the poor. This constituency in return rallies behind the more overtly political actions of the movement, such as marches, demonstrations or petitions. Evidence of the same kind can be found when one examines Islamist movements in Palestine or Lebanon. In the case of Morocco, Beau and Graciet argue that the ability to Islamicise society through charity and social work will inevitably have significant political consequences, namely a reduction of the Monarchy's legitimacy and therefore the certainty that Islamism will eventually triumph. While this scenario might be overly pessimistic for the Monarchy, the influence of Islamism in Morocco should not be underestimated. Paradoxically, the surprisingly disappointing score of the Islamist Party of Justice and Development at the September 2007 legislative elections might be an indication that the societal Islamism represented by Sheikh Yassine's association is indeed on the rise. Given the group's uncompromising attitude towards current electoral consultations, the very poor turnout reflects well on the movement as a non-participant. It means that the attitude that the group has towards meaningless elections is widespread in society and that other means of political action, namely social work, are much more significant. The Moroccan situation might indeed be peculiar and odd when compared to other countries in the region, but Clark's assertion that Islamism is purely a middle-class phenomenon does not take into account the still widespread appeal it exercises on the poor precisely because of the charitable work that Islamic social institutions do. Thus, the strength a of their social work and ideological discourse still has a 'universal' appeal and is capable of attracting 
different social categories to its message of change. This does not necessarily undermine completely her analysis because Clark is correct in pointing out that the 'catch-all' tendency of Islamist movements might not serve them well in the future due to the internal contradictions that such tendency generates. In conclusion, while in the long run and through their institutionalisation into political parties, this catch all trait may not be satisfactory for the electorate, at the moment it seems that Islamic civil society activism is still largely coherent and intent on projecting a message of unity through which the interests of the whole nation can be expressed because the creation of an Islamic state will provide the necessary institutional framework to represent and satisfy the needs of all social classes.

\section{$\underline{\text { Trends and directions }}$}

In-depth examinations of civil society dynamics and their impact on prospects of democratisation in the Arab world have been very much at the forefront of academic scholarship in recent years. The policy emphasis on the strengthening of civil society activism requires a better understanding of the role of civil society that goes beyond the traditional conventional wisdom, which sees a causal relationship between increasing civic vibrancy and demands for democratisation in authoritarian settings. The four volumes reviewed here provide such understanding in a number of aspects.

First of all, from all the studies it emerges that strengthening civil society activism is unlikely to lead to democratisation, although for slightly different reasons. Pratt argues that the secular and liberal democratic discourse is too marginal at the moment to be able to construct a mode of understanding state-society relations that is not potentially authoritarian. The main problem with this view is that it seems to categorise Islamism as inherently anti-democratic. While Islamism indeed produces a 
hegemonic alternative discourse in the construction of an Islamic society where specific interests are subsumed to a renewed effort of non-Western modernisation, evidence suggests that more often than not it is secular and nominally liberal civil society that rallies to the authoritarian regime to stop political Islam from taking over. This is indeed a key, but often overlooked point in the current debate and contributes to explain what can be called the 'paradox of strength'. In the face of similar authoritarian constraints, it would seem logical that all opposition groups within civil society would cooperate to bring about change. The vibrancy of associational life and the widespread criticism of authoritarianism should theoretically lead to an increase in democratic attitudes and behaviour, which, in turn, should lead to political reforms. However, co-operation and alliance-building between the two sectors of civil society on the basis of shared objectives and values occurs only rarely because of the sharp ideological conflicts that exist between Islamist and secular/liberal groups, which translate into radically conflicting policy preferences. This division is based on a fundamentally opposing objective. While Islamists wish to make Islam the central reference for policy-making, secular/liberal groups wish to take Islam completely out of politics. This means that there is no shared democratic discourse that can unite them because they have conflicting views on the values, if not the procedures, that should underpin the new society they all hope to create. This division allows authoritarian regimes to use 'divide and conquer' strategies in order to remain in power. The outcome is that too many secular and liberal groups have "proven too willingly to cooperate with local non democratic regimes' (Cook, 2005:94).

Jamal argues that fostering civic activism has a detrimental effect on democratisation because the authoritarian setting privileges pro-regime associations, which do not have any incentive in democratic change because they will lose their access and 
therefore their material gains. Similarly, Clark contends that civil society activism, even of the Islamic tendency, tends not to greatly upset authoritarian structures because Islamic social institutions end up co-operating on many matters with the regime. Finally, Beau and Graciet conclude that fostering civil society activism would benefit only Islamist groups as they are the ones currently dominating society and the political consequences of their taking over the state might lead to a form of renewed authoritarianism. Thus, evidence from the Arab world seems to point to the absence of a link between civil society activism and democratisation; on the contrary, it seems that such activism is an advantage for the ruling elites. These findings legitimate the doubts that are being expressed in the wider literature on democratisation about the usefulness of civil society as an explanatory variable.

The second important aspect emerging from these volumes is the dominant role of Islamism. While this was to be expected, it is important to underline that Islamist movements are much less ideological than usually believed. While the members of these groups interpret their activism as a form of political work and the organisations themselves use their charity work as a showcase for their abilities, their everyday actions are very much informed by rationality. Thus, they compromise and cooperate with the regime and with other 'opposition' groups on ad hoc matters if this advances the interests of the association irrespective of significant ideological differences, although they never do so on a sustained basis.

Finally, a third aspect is the much stronger relevance of charity and developmental work than of sheer political activism. The appeal of Islamism is due to the social engagement of Islamist movements. While such charity work is certainly beneficial to the middle-class, it is also helpful for the poor, which then become attached to Islamism as a political project. This in turn allows Islamists to present a 
coherent and unitary project of modernisation that incorporates the interests of all social classes. It is on this terrain where they have virtually no competition and this excludes other ideas and ideological references from being heard.

These three aspects have a considerable impact on how we can evaluate strategies of democracy promotion. The current strategy of international donors of attempting to empower those groups within society claiming to be of the same liberal inspiration is simply not working. Liberal and secular groups emphasising individual rights and procedural democracy do not reflect the preoccupations of the vast majority of the population. Not only they are out of touch with the masses, but they also tend to rally to the regime in order to halt the growth of Islamism, thereby betraying their supposedly liberal-democratic ethos. Finally, these groups are often accused of promoting western values and interests at a time when western policies in the region are highly controversial. The corollary of the current strategy is to avoid relations with Islamist movements, negating a priori their democratic credentials. This is done in the name of a combination of both ideological incompatibility and realpolitik necessities, but it achieves only the objective of further alienating such movements.

In light of the findings and analyses of the four volumes reviewed it seems that if achieving democracy, or at least a procedural version of it, were the objective of the international community, a fundamental policy shift should occur. There are two priorities that should be pursued. First of all, much stronger pressure should be put on authoritarian regimes themselves to reform rather than insisting on strengthening an associational life, which is ultimately ineffective. Much greater effort should be put in undermining the stability of authoritarianism in order to liberate society and let it organise accordingly. Secondly, emphasis should be placed in enhancing the developmental goals of civil society and therefore investing in associations promoting 
and providing welfare. This would certainly include cooperating or at least offering to cooperate with Islamic institutions. While it might be difficult to channel funds to development-oriented organisations while undermining the stability of the authoritarian regimes, this should at least be attempted. Many would point out that such strategy, if successful, would deliver Islamism in power. This might indeed be true, but any outcome is more likely to be the expression of popular will than current arrangements. In addition, according to Clark's study, there are two points to consider. First of all, Islamic social and political institutions are much more rational than believed, which means that cooperation with them could lead to moderation and compromise. Secondly, if the poor are really up for grabs as an electoral constituency, the victory of Islamism is by no means a foregone conclusion.

\section{References}

Berman, Sheri (2003), Islamism, Revolution and Civil Society, Perspectives on Politics, 1(2), pp. 257272.

Brumberg, Daniel (2002), Islamists and the politics of consensus, Journal of Democracy, 13(4), pp. 109-115.

Carothers, Thomas (1999/2000), Civil Society, Foreign Policy, 117, pp. 18-29.

Cavatorta, Francesco (2006), 'Civil society, Islamism and democratisation: the case of Morocco', Journal of Modern African Studies, 44(2), pp. 203-222.

Cook, Steven (2005), The right way to promote Arab reform, Foreign Affairs, 84(2), pp. 91-102.

Encarnacion, Omar (2006), Civil society reconsidered, Comparative Politics, 38(3), pp. 357-376.

Tempest, Clive (1997), Myths from Eastern Europe and the Legend of the West, Democratization, 4(1), pp. 132-144.

Wiktorowicz,Quintan (2000), Civil society as social control. State power in Jordan, Comparative Politics, 33(1), pp. 43-61.

Yom, Sean (2005) Civil society and democratization in the Arab world, Middle East Review of International Affairs, 9(4), pp. 14-33. 